\title{
Critically Important: The Heterogeneous Effect of Diplomatic Tensions on Trade
}

\author{
Julian Hinz ${ }^{1}$ (D) Elsa Leromain ${ }^{2,3}$
}

Published online: 15 July 2020

(c) The Author(s) 2020

\begin{abstract}
With global value chains interlocking today's economies, what is the impact of diplomatic tensions on international trade? We exploit variation in monthly data on imports, a measure of imported input use in the domestic economy, and the incidence of bilateral diplomatic tensions to show that their impact on trade is heterogeneous across countries and industries. Trade in industries that are crucial for domestic production is more sensitive to political tensions. We expose the underlying mechanism in a simple framework before testing it in reduced form.
\end{abstract}

Keywords Diplomatic tensions · Political relations · Trade

"Multinationals are very nervous now, and they should be. [...] In the past, only some sectors-mining, oil and gas, commodity companies-had to worry about geopolitics. Now companies that make fizzy drinks or handbags or chocolate are finding their supply chains, their markets, their operations completely blown apart by geopolitical risks and unfavorable treatment."

— Mark Leonard, co-founder of the European Council on Foreign Relations. ${ }^{1}$

\footnotetext{
1 From "The great unraveling of globalization", Washington Post by Jeffrey Rothfeder on April 24, 2015.

Formerly circulated under the title "Politics of Global Value Chains".

Julian Hinz

mail@julianhinz.com

Elsa Leromain

elsa.leromain@uclouvain.be

1 Kiel Institute for the World Economy, and Kiel Centre for Globalization, Kiellinie 66, 24105 Kiel, Germany

2 IRES/LIDAM, Université Catholique de Louvain, Place Montesquieu 3/L2.06.01, 1348 Louvain-la-Neuve, Belgium

3 Centre for Economic Performance, London School of Economics, London, UK
} 


\section{Introduction}

Recent years have seen a resurgence of political tensions between countries. While occasions when states threaten the use of military force are rare, diplomatic tensions are frequent. Flare-ups of disagreement or personal hostility between the leaders of two countries increases uncertainty of the future of bilateral political relations. At the same time, the proliferation of international supply chains has made the domestic production of goods increasingly dependent on inputs from foreign sources. By expanding their sourcing portfolio to foreign suppliers, firms and by extension entire economies are more prone to the trade effects of adverse bilateral political shocks.

The political fall-out of the poisoning of Sergei and Yulia Skripal is a case in point. In early March 2018 the former Russian spy and his daughter were poisoned with a military-grade nerve agent of a type developed by Russia. ${ }^{2}$ The British Prime Minister made a statement in parliament, seeking an explanation from Russia. ${ }^{3}$ By March 14, the UK had expelled 23 Russian diplomats who were identified as undeclared intelligence officers and had suspended all planned high-level contact. On March 17, Russia summoned the United Kingdom's ambassador to Russia; 33 members of the diplomatic staff in Moscow were declared persona non grata, and were expelled from Russia within a week. The UK then closed its consulate in St. Petersburg, and the British Council office in Moscow. ${ }^{4}$

Interestingly, as Fig. 1 shows, the incident may also have had a noticeable and peculiar impact on bilateral trade between the two countries. Figure 1a contrasts the UK's (smoothed) imports from Russia against the imports by other European countries from Russia. The former shows a marked drop in total imports precisely around the time of the incident. Other European countries did not register such a decline. However, the impact on UK imports appears to have been heterogeneous across different types of goods, as depicted by Fig. 1b. Intermediate goods-those that are intended for use in the production of other goods in the UK-such as metals and mineral products, appear to have taken a much more severe hit than did final products, such as foodstuffs or machinery.

The aim of this paper is to investigate the impact of bilateral diplomatic relations on trade; we focus on why some sectors may be more sensitive than are others. We show in a stylized theoretical framework why certain industries may be more prone to disruption as a result of diplomatic tensions than are others, and we test the main hypothesis empirically.

The model assumes a two-sector and many-countries world, where a "diplomatic shock" may affect the sourcing decision of a representative firm for imported inputs.

\footnotetext{
${ }^{2}$ See e.g. https://www.theguardian.com/uk-news/2018/mar/07/russian-spy-police-appeal-for-witnessesas-cobra-meeting-takes-place.

3 See https://www.theguardian.com/uk-news/2018/mar/12/russia-highly-likely-to-be-behind-poisoningof-spy-says-theresa-may.

${ }^{4}$ Over the course of 2018 the number of diplomats who were expelled from either side-in addition to those from a number of UK-allied countries-rose to an astonishing 342 (https://www.aljazeera.com/ indepth/interactive/2018/04/skripal-case-diplomatic-expulsions-numbers-180402121217839.html. This underlines the severity of this particular diplomatic incident.
} 


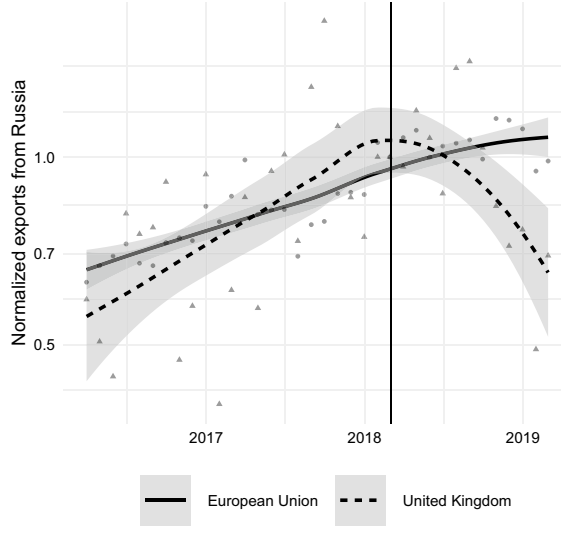

(a) Russian exports to UK and EU

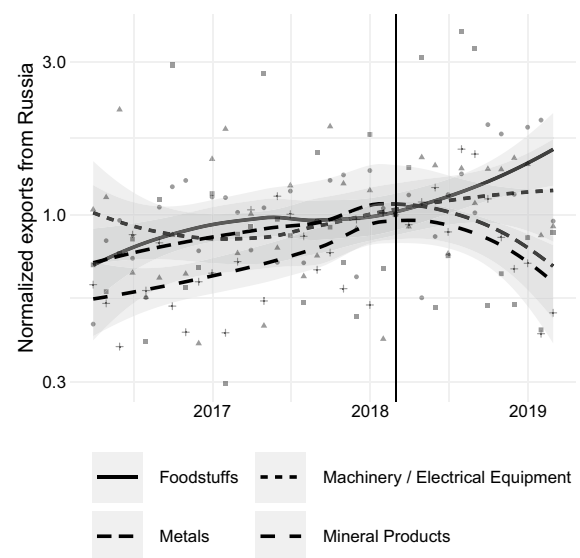

(b) Russian export to UK by select HS sections

Fig. 1 Impact of diplomatic tensions on UK-Russia trade

The model shows that this effect may be heterogeneous across sectors, even when the shock is homogeneous. The key determinant of the heterogeneity is the degree to which the imported input is used directly and indirectly in the production process, and whether viable alternative sourcing countries exist. The model thus captures an important feature of today's global economy: Goods that are produced in one country are often used as an input in another country. Disruptions to trade-whether through an increase in tariffs or political tensions-thus do not only affect consumers directly, but also affect production of down-stream products.

We test the proposed mechanism in reduced form: We first construct a measure of the intensity of imported input use that follows from the model; we characterise how important certain imports are for certain countries. We then exploit variation in monthly data on imports and the incidence of bilateral diplomatic events. We use a novel dataset that records diplomatic events that are found in press releases that were collected from the websites of the foreign ministries of five politically and economically important countries: the United Kingdom, Germany, France, Japan, and Russia.

We contribute to the literature that studies the effect of diplomatic relations on trade. Measuring diplomatic relations and their evolution over time is challenging. Some authors have used direct measures of an increase in political ties, such as the presence of embassies (Rose 2007) or official visits of heads of state (Nitsch 2007). Others measure changes in political relations more indirectly: They use specific events such as the Dalai Lama's visits to foreign countries (Fuchs and Klann 2013; Lin et al. 2019) or boycott campaigns (Heilmann 2016); voting similarities between countries at the UN General Assembly (Mityakov et al. 2013); or asylum policies (Cucu and Panon 2020). We add to previous studies by emphasizing the country-industry-specific heterogeneity of the impact, due to global value chains' shaping countries' dependence in imported inputs. We 
furthermore propose a novel measure that clearly identifies the beginning of diplomatic tensions with an official recorded action taken by a government.

The literature provides strong evidence that political relations affect trade. However, the underlying mechanism depends on the context: Heilmann (2016) shows that the effect on trade is driven mainly by changes in the attitudes of consumers; while in Fuchs and Klann (2013) the aggregate effect is driven by industries for which negotiations are carried out during the course of high-ranking governmental trade negotiations.

Most similar to our paper is the work by Michaels and Zhi (2010), who study the impact of the French opposition to the Iraq war in 2003 on bilateral flows between the US and France. They find evidence that French exports to the US dropped significantly-especially for intermediate inputs. Their finding is consistent with a change in managers' attitudes towards France. Acknowledging the importance of intermediate inputs, we show in a simple framework that trade in inputs that are used intensively directly and indirectly by the importing economy are more prone to disruption by diplomatic tensions than is trade in other products.

Our paper also addresses the growing strand of the literature that stresses the role of uncertainty and changing expectations in shaping economic outcomes. One prominent example is the United Kingdom's vote to leave the European Union, which affected important economic outcomes: stock market prices (Breinlich et al. 2018; Davies and Studnicka 2018); GDP (Born et al. 2019); and trade flows (Crowley et al. 2018). In another context, in relation to the sanctions against the Russian Federation in response to the events in eastern Ukraine and Crimea in 2014, Crozet and Hinz (2020) show that even products that were not directly targeted by any measure experienced a decline in exports to Russia. They show that those products that rely on trade finance instruments-e.g., letter-of-credit financing of a transaction-fared worse than other products.

Finally, the paper is related to a resurgence of interest in the evaluation of trade policy changes and disruptions to trade in a time of tightly-connected economies through global value chains. Two recent papers-Fajgelbaum et al. (2019) and Amiti et al. (2019) — study the impact of tariffs that were imposed by the Trump administration against China; the papers rely on state-of-the-art models that exhibit domestic and international input-output linkages. In a project that re-evaluates the results by Ossa (2014) and Felbermayr et al. (2013), who find surprisingly optimal high tariffs, Romalis et al. (2019) investigate optimal trade subsidies and tariffs in a world that is characterized by global value chains; they find-on average-much lower and, importantly, much more heterogeneous optimal trade policies across countries and industries. While our model sketches a more stylized view of the global economy, it shares this feature of domestic and international input-output linkages while investigating the impact of bilateral policies that impact trade.

The paper is structured as follows: In Sect. 2 we sketch a simple framework that formalizes the mechanism, where those imported inputs that are used intensively directly and indirectly in an economy are more sensitive to political tensions, given that viable sourcing alternatives exist. We describe the data we use to test this mechanism in Sect. 3, while Sect. 4 lays out the empirical strategy. The econometric 
results are discussed in Sect. 5, and robustness tests are discussed in Sect. 6. Section 7 concludes.

\section{A Simple Model}

A simple stylized model can help in understanding why, in a world with global value chains, the impact of homogeneous bilateral political disruptions may be heterogeneous across industries.

Assume a world with a home country and a number of foreign countries. A representative firm in the home country produces two goods, $x$ and $y$, that are combined into an output bundle to be consumed by the representative consumer. ${ }^{5}$ For the production of each, the firm uses labor, its own other good, and two imported inputs: $m$ and $n$. These can be sourced from foreign countries at different prices, such that there is a ranking from the cheapest to the most expensive source for each input. Let $\varepsilon_{m}$ and $\varepsilon_{n}$ describe the price gap between the cheapest and the second-cheapest source.

The production for $x$ and $y$ is of a Cobb-Douglas type such that:

$$
\begin{aligned}
& x=l_{x}^{\lambda_{x}} y_{x}^{\beta_{x}} m_{x}^{\gamma_{x}} n_{x}^{\delta_{x}} \text { and } y=l_{y}^{\lambda_{y}} x_{y}^{\alpha_{y}} m_{y}^{\gamma_{y}} n_{y}^{\delta_{y}} \\
& \text { where } \quad \lambda_{x}+\beta_{x}+\gamma_{x}+\delta_{x}=\lambda_{y}+\alpha_{y}+\gamma_{y}+\delta_{y}=1
\end{aligned}
$$

and the firm's output bundle is given by

$$
Y=x^{\eta} y^{1-\eta} \quad \text { with } \quad 0 \leq \eta \leq 1 .
$$

The corresponding prices of the imported inputs, $p_{m}$ and $p_{n}$, include all costs associated with shipping, including costs for trade finance services, such as insurance that covers the failure of a timely delivery. For the purposes of the argument, assume that the firm sources $m$ and $n$ from the same foreign country initially, as this is the cheapest source available for both inputs. Then consider a negative shock to political relations between the home country and this foreign country. Assume that this shock introduces or increases uncertainty about whether the input that is sourced from abroad actually arrives, which increases the price of insuring or financing a transaction, and hence translates into an increase in the price of $m$ and $n .{ }^{6}$ Let $\zeta$ measure the difference between the price of inputs from this foreign country before and after the shock.

The firm aims at minimizing the effect of the shock on its output bundle, with two possible options for each input:

\footnotetext{
${ }^{5}$ Equivalently, one could model the consumer to have a Cobb-Douglas utility function with shares $\eta$ and $1-\eta$ for the two goods.

${ }^{6}$ C.f. Crozet and Hinz (2020), who show that sanctions against the Russian Federation in the response to the events in eastern Ukraine and Crimea also affected those goods that were actually not directly targeted in any way-likely through more expensive trade finance instruments.
} 
1. The price-increase leads to a reduction of imports from the foreign country;

2. The firm starts sourcing from another foreign country, subject to a switching cost $\omega>0$.

Following Eqs. (1) and (2), we can express the benefits of switching suppliers for input $m$ as follows:

$$
\begin{aligned}
& \left|\frac{\partial \log (Y)}{\partial p_{m}}\right|_{\text {switch }}-\left|\frac{\partial \log (Y)}{\partial p_{m}}\right|_{\text {switch }} \\
& =\left(\zeta-\varepsilon_{m}\right) \frac{1}{p_{m}}\left(\eta\left(\gamma_{x}+\beta_{x} \gamma_{y}\right)+(1-\eta)\left(\gamma_{y}+\alpha_{y} \gamma_{x}\right)\right)
\end{aligned}
$$

and for input $n$ accordingly. If the benefits outweigh the switching costs, the firm switches supplier; i.e., when

$$
\left(\zeta-\varepsilon_{m}\right) \frac{1}{p_{m}}\left(\eta\left(\gamma_{x}+\beta_{x} \gamma_{y}\right)+(1-\eta)\left(\gamma_{y}+\alpha_{y} \gamma_{x}\right)\right)>\omega
$$

For a given $\omega$ and $\zeta$, the switch depends on:

1. The sign of $\zeta-\varepsilon_{m}$ : whether the price change is larger than the initial price gap;

2. The magnitude of the term $\left(\eta\left(\gamma_{x}+\beta_{x} \gamma_{y}\right)+(1-\eta)\left(\gamma_{y}+\alpha_{y} \gamma_{x}\right)\right)$, i.e. the importance of this input in direct and indirect use in the production.

For $\zeta-\varepsilon_{m}<0$, the firm does not switch. If, however, the initial price gap is smaller than the price change, the importance of the input for output bundle determines whether a switch occurs. A high direct and indirect use of the input leads to a significant change in output bundle, which may be larger than the fixed costs for switching. Hence, even for the same shock $\zeta$ and the same fixed costs of switching $\omega$, imports of inputs $m$ and $n$ may differ in their response to the shock, due to differences in the initial price gap and their use in the firm's production process.

The simple model displays one mechanism through which political shocks may have a heterogeneous effect on trade flows. In the real world, economies consist of many firms, which source many inputs from many suppliers. Yet, even when abstracting from these complexities, the following hypothesis should hold: A negative shock to bilateral political relations leads to a general decrease in trade flows. The response should be larger for products in markets with a small price gap and a high imported input use. In other words, a country's involvement in global value chains thus exposes it to greater dependence on upstream inputs, if alternative sourcing partners are rare. 


\section{Data}

We test the hypothesis with the use of the incidence of diplomatic events as a proxy for negative shocks to bilateral diplomatic relations, in combination with industrylevel data on monthly bilateral trade and input-output tables to capture the direct and indirect use of imported inputs.

\subsection{Diplomatic Events}

As noted above, summoning or recalling high-level diplomats is used as a diplomatic instrument to signal discontent and put pressure on a foreign government. We collected data on the actions taken by the United Kingdom, Germany, France, Japan, and the Russian Federation; all are lead actors in the political arena as well as in trade, combined accounting for $25 \%$ of world imports. ${ }^{7}$ The five countries have repeatedly made use of the summoning or recalling of diplomats as an instrument of foreign policy. We have collected information on these events over the time period from 2010 until 2014 from official press releases that are available on the website of each Ministry of Foreign Affairs; ${ }^{8}$ we use keyword searches such as "ambassador summoned", "ambassador recalled", "withdrawal of diplomatic staff", "embassy closure". 9

\subsection{Trade Flows}

We use data on monthly trade flows from UN Comtrade (United Nations Statistics Division 2015). We extract data on the imports of the five countries vis-à-vis the rest of the world-241 countries and territories_-from January 2010 to December 2014 (60 months). We aggregate the data into 16 manufacturing sectors as defined in WIOD to match the level of aggregation of our import use measure that we describe below.

\footnotetext{
${ }^{7}$ Three of the five countries-France, the United Kingdom, and the Russian Federation—are permanent members of the UN Security Council. Notably absent from the list of countries are the United States and China, whose foreign policy clearly shapes global events and likely influences trade flows. Unfortunately, however, the US State Department does not make public instances in which these instruments of diplomacy are used. The Chinese Ministry of Foreign Affairs does publish press releases, but it is technically difficult to retrieve them en masse, as the website does not allow searches of its archive.

8 "Appendix A.1" lists the direct weblinks to the different websites.

${ }^{9}$ A diplomat may be summoned or recalled for different reasons, as some examples of events show: In November 2010, Russia summoned the Canadian ambassador over new visa requirements for Russian nationals; in February 2011, France summoned the Mexican ambassador with regard to the situation of the French-national Florence Cassez; in July 2012, Japan summoned the Chinese ambassador to protest against the entry of patrol ships into disputed territorial waters; in March 2013, Germany summoned the Chinese ambassador to condemn an attack on a German journalist; in June 2014, the British Foreign Office summoned the Egyptian ambassador following an Egyptian court's guilty verdicts against Egyptian and international journalists. More details on these cases and a complete list of events can be found in "Appendix A.2".
} 


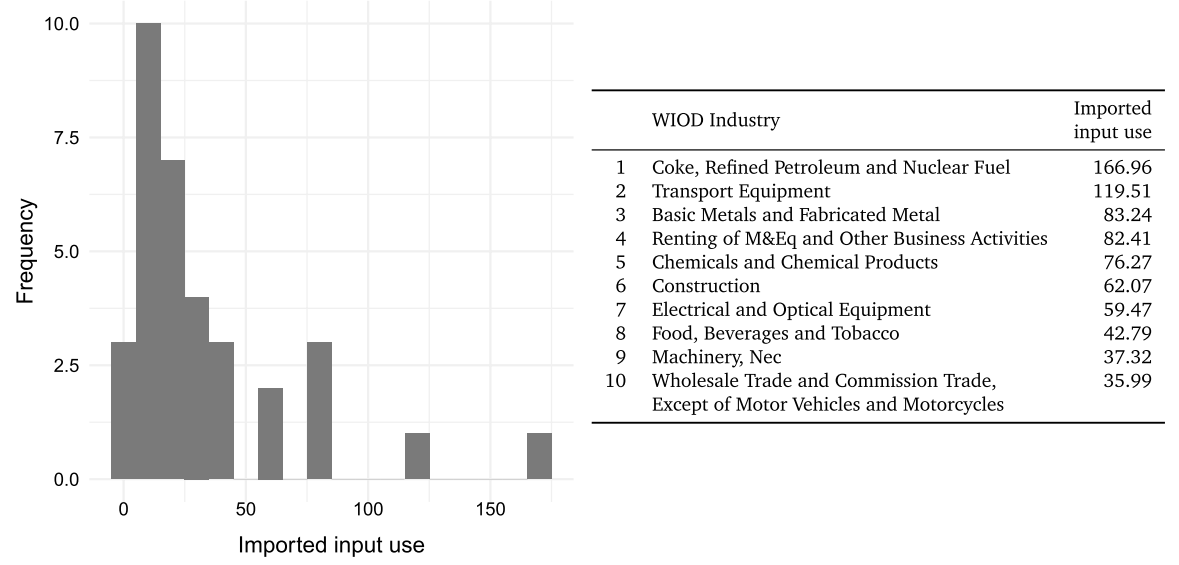

(a) Histogram of imported input use for 34 sectors

(b) Top 10 imported input sectors

Fig. 2 Histogram and top 10 imported input use per 1000 USD GDP for UK

\subsection{Imported Input Use}

The simple model in Sect. 2 postulates that one key determinant of the response to the shock is the country's involvement in global value chains, through its direct and indirect use of imported inputs. The term $\left(\eta\left(\gamma_{x}+\beta_{x} \gamma_{y}\right)+(1-\eta)\left(\gamma_{y}+\alpha_{y} \gamma_{x}\right)\right)$ can easily be translated into a multi-product setting, including domestic production of inputs, as

$$
\mathrm{IIU}_{d}=A_{d, i m p}\left(I-A_{d, d o m}\right)^{-1} F_{d}
$$

where $A_{d, i m p}$ is the matrix of the values of imported inputs by sector in country $d$ and $A_{d, d o m}$ the matrix of the values of domestic inputs by sector. $F_{d}$ is the vector of final consumption shares. Each element of the vector $\mathrm{IIU}_{d}$ denotes the required value of a foreign input for a 1-unit value of final consumption in the domestic economy for a given sector $k$. The higher is the necessary imported value, the more important is the input for the country's economy. We compute the measure for the five countries of interest with the use of the global input-output table for the year 2008 from the World Input Output Database (Timmer et al. 2015). ${ }^{10}$ The table covers 34 sectors that encompass both manufacturing and services.

10 Relying on data from 2008 ensures the exogeneity of the input coefficients for the event study. 
Figure 2 shows the histogram of all the 34 sectors and the ranking of the 10 most important imported inputs sectors for the United Kingdom. ${ }^{11}$ The ranking and magnitude are sensible, with petroleum and metals ranking first and third in terms of imported input use. Farther down-stream goods - such as food products and machinery-are ranked eighth and below. Figure $1 \mathrm{~b}$ in the introduction is consistent with such a ranking, where the former two accounted for the bulk of the decrease in UK imports from Russia in the aftermath of the Skripal poisoning, whereas the latter two saw little impact.

\section{Empirical Strategy}

Our aim is to analyze how imports respond to a negative shock to diplomatic relations, and test whether imports in sectors with a high import input use and a small price gap decrease relatively more than imports in other sectors. Our dependent variable is hence (the logarithm) of monthly imports by industry and source country. The treatment is an indicator for the occurrence of a diplomatic incident, coded as described above. We take import flows from other countries that are never treated as the control group. ${ }^{12}$

This obviously would be a problematic assumption if we were interested in only the estimated coefficient of this treatment. Import flows could be redirected from the treated source country to another source country from the control group and thus bias upwards the estimated coefficient. However, we are primarily interested in the interaction of the treatment with country-industry and industry-specific variables, which should not be affected.

The equation we estimate is

$$
\begin{aligned}
\log \left(X_{\text {odkt }}\right)= & \delta_{0} \cdot \text { Treatment }_{\text {odt }} \\
& +\delta_{1} \cdot \text { Treatment }_{\text {odt }} \times \log \left(\mathrm{IIU}_{d k}\right) \\
& +\delta_{2} \cdot \text { Treatment }_{\text {odt }} \times \text { Concentration }_{k} \\
& +\delta_{3} \cdot \text { Treatment }_{\text {odt }} \times \log \left(\mathrm{IIU}_{d k}\right) \times \text { Concentration }_{k} \\
& +\boldsymbol{\Gamma}+\epsilon_{\text {odkt }}
\end{aligned}
$$

We interact the Treatment variable with a proxy for the industry-specific price gap, Concentration $_{k}$, and the country-industry-specific imported input use measure, $I I U_{d k}$. To measure the price gap on the sourcing market we compute a Herfindahl

\footnotetext{
11 We also compute the measure for the most detailed openly available input-output table, for the United States from the Bureau of Economic Analysis, with data on 389 industries, and compare it with the respective measure that is computed with the use of WIOD data. The results are displayed in Table 4 in "Appendix B". The direct comparison shows consistent figures by ranking and magnitude across these different levels of aggregation. Unfortunately, input-output tables of this great detail are a rarity for other countries.

12 As there is a small number of country pairs that do not entertain bilateral diplomatic representations, e.g. North Korea and France do not have official diplomatic relations, we consider only country pairs that do have embassies or consulates in each other's country in the analysis.
} 
index of total exports across source countries with trade data for 2010. The underlying assumption is that the greater the Herfindahl index, the lower is the level of competition, and thus the higher is the price gap in this industry. We normalize the imported input use measure by the respective country's average imported input use and take the logarithm. Thus, the interpretation of the coefficients is straightforward, as the benchmark is an industry with an infinitely small price gap and the average imported input use of the importer.

We control for unobservable characteristics with the use of different sets of time, importing country, source country, and industry fixed effects, which are denoted by the vector $\boldsymbol{\Gamma}$. More specifically, in a different specification we control for exporterdate and importer-date-specific, or even exporter-industry-date and importer-industry-date-specific characteristics, such as demand and supply shocks. Importantly, these sets of fixed effects also address concerns that diplomatic incidents may reflect broader political changes in the countries in question, which would affect all economic activity and confound the effect of bilateral diplomatic relations. We also include bilateral directed country-pair-industry, and country-pair-industry-month fixed effects that capture all time-invariant trade barriers, and in the latter case also seasonal effects. Through these fixed effects the coefficients hence reflect a comparison to a state of "normal" bilateral relations, which take into account bilateral historical episodes, such as previous colonial ties.

The coefficient on the Treatment variable - $\delta_{0}$ - is the average effect for the benchmark: a small price gap and the average imported input use of the importer, which we expect to have a negative sign. The main test of our prediction comes from the interaction between Treatment $\times \log (I I U)_{d k}$. In our simple framework, we show that the effect should be magnified by the degree of imported input use, given a small price gap. The coefficient of the interaction between Treatment $\times \log (I I U)_{d k}$ $-\delta_{1}$ - is therefore expected to be negative.

The remaining interaction terms are necessary for the test, but the interpretation of their coefficients $-\delta_{2}$ and $\delta_{3}$-is not explicitly guided by the framework. We would, however, expect positive coefficients. In principle, lower concentrationhigher price gaps - should yield a lower response of import flows and a more muted influence for those industries with high imported input use.

\section{Results}

The results from estimating Eq. (4) are presented in Table 1. There are a total of 40 events. For those country pairs for which we observe several events over the period, we use the date of the first one to construct the treatment variable. ${ }^{13}$ The two main coefficients of interest- $\delta_{0}$ and $\delta_{1}$ - are negative and very stable across specifications with different sets of fixed effects $\boldsymbol{\Gamma}$. The effects are in line with the hypothesis from the framework in Sect. 2. The overall effect of political tensions on trade is negative, and more pronounced for important inputs to the

${ }^{13}$ See "Appendix A.2" for the full list of events. 
Table 1 Event study_political shock and heterogeneous effect

\begin{tabular}{|c|c|c|c|}
\hline & \multicolumn{3}{|c|}{ Dependent variable } \\
\hline & \multicolumn{3}{|l|}{$\log$ (imports) } \\
\hline & (1) & (2) & (3) \\
\hline Treatment & $\begin{array}{l}-0.083^{* * *} \\
(0.026)\end{array}$ & $\begin{array}{l}-0.074 * * \\
(0.033)\end{array}$ & $\begin{array}{l}-0.083 * * \\
(0.035)\end{array}$ \\
\hline Treatment $\times \log (\mathrm{IIU})$ & $\begin{array}{l}-0.069 * * * \\
(0.021)\end{array}$ & $\begin{array}{l}-0.051^{*} \\
(0.028)\end{array}$ & $\begin{array}{l}-0.061 * * \\
(0.031)\end{array}$ \\
\hline Treatment $\times$ concentration & $\begin{array}{l}0.699 * * \\
(0.301)\end{array}$ & $\begin{array}{l}0.568 \\
(0.407)\end{array}$ & $\begin{array}{l}0.672 \\
(0.446)\end{array}$ \\
\hline Treatment $\times$ concentration $\times \log (\mathrm{IIU})$ & $\begin{array}{l}0.571 * * * \\
(0.168)\end{array}$ & $\begin{array}{l}0.426^{*} \\
(0.218)\end{array}$ & $\begin{array}{l}0.486 * * \\
(0.243)\end{array}$ \\
\hline Fixed effects & $\begin{array}{l}\text { ctry-dt, } \\
\text { pair-ind }\end{array}$ & $\begin{array}{l}\text { ctry-ind-dt, } \\
\text { pair-ind }\end{array}$ & $\begin{array}{l}\text { ctry-ind-dt, } \\
\text { pair-ind-mo }\end{array}$ \\
\hline Observations & 410,303 & 410,303 & 410,303 \\
\hline $\mathrm{R}^{2}$ & 0.913 & 0.951 & 0.964 \\
\hline Adjusted $\mathrm{R}^{2}$ & 0.909 & 0.925 & 0.922 \\
\hline
\end{tabular}

Robust standard errors: $* p<0.1 ; * * p<0.05 ; * * * p<0.01$

domestic economy. An economy's dependence on foreign upstream production makes it vulnerable to adverse bilateral shocks with the supplying country.

In column (1) we include importing country $\times$ date, sourcing country $\times$ date, and country pair $x$ industry fixed effects to control for unobserved characteristics. In columns (2) and (3) we are even more restrictive and augment the country $\times$ date fixed effects by an industry, and calendar month dimension. While this leaves very little variation in the data, the estimated coefficients persist.

The estimates of $\delta_{0}$ range between -0.074 and -0.083 , which translates into an average decrease in imports in reaction to a shock to political relations for the reference group in the preferred specification (1) of $\exp (-0.083)-1=-8 \%$. Although, as described above, the estimates have to be taken with caution, the magnitude of the effects mirrors very well the results from the related literature. Michaels and Zhi (2010) find an 8\% drop in bilateral trade between France and the US in response to the Iraq war, while Nitsch (2007) reports an increase of $8-10 \%$ in exports after the visit of a head of state.

The estimates of $\delta_{1}$ range between -0.051 and -0.069 , which corresponds to an additional $\exp (-0.069)-1=-6.7 \%$ decrease in imports for a sector with import use twice as high as the average for the preferred specification.

The coefficients $\delta_{2}$ and $\delta_{3}$ both have positive coefficients, which confirms the intuition that lower concentration in an industry yields a lower response of import flows, and a smaller role for imported input use. 
Table 2 Robustness test-country samples and industry-specific measures

\begin{tabular}{|c|c|c|c|c|c|}
\hline & \multicolumn{5}{|c|}{ Dependent variable } \\
\hline & \multicolumn{5}{|l|}{$\log$ (imports) } \\
\hline & (1) & (2) & (3) & (4) & (5) \\
\hline Treatment & $\begin{array}{l}-0.082 * * * \\
(0.027)\end{array}$ & $\begin{array}{l}-0.055^{* *} \\
(0.028)\end{array}$ & $\begin{array}{l}-0.085^{* * *} \\
(0.029)\end{array}$ & $\begin{array}{l}-0.119 * * \\
(0.061)\end{array}$ & $\begin{array}{l}-0.098^{* *} \\
(0.040)\end{array}$ \\
\hline Treatment $\times \log (\mathrm{IIU})$ & $\begin{array}{l}-0.079 * * * \\
(0.022)\end{array}$ & $\begin{array}{l}-0.060^{* * *} \\
(0.022)\end{array}$ & $\begin{array}{l}-0.042^{*} \\
(0.023)\end{array}$ & $\begin{array}{l}-0.072 * * * \\
(0.022)\end{array}$ & $\begin{array}{l}-0.071 * * * \\
(0.021)\end{array}$ \\
\hline Treatment $\times$ concentration & $\begin{array}{l}0.624 * \\
(0.331)\end{array}$ & $\begin{array}{l}0.452 \\
(0.343)\end{array}$ & $\begin{array}{l}0.675 * * \\
(0.314)\end{array}$ & $\begin{array}{l}0.697 * * \\
(0.302)\end{array}$ & $\begin{array}{l}0.680 * * \\
(0.304)\end{array}$ \\
\hline $\begin{array}{l}\text { Treatment } \times \text { concentra- } \\
\text { tion } \times \log (\mathrm{IIU})\end{array}$ & $\begin{array}{l}0.563 * * * \\
(0.183)\end{array}$ & $\begin{array}{l}0.382 * * \\
(0.182)\end{array}$ & $\begin{array}{l}0.364 * * \\
(0.177)\end{array}$ & $\begin{array}{l}0.587 * * * \\
(0.169)\end{array}$ & $\begin{array}{l}0.573 * * * \\
(0.168)\end{array}$ \\
\hline Treatment $\times$ labor intensity & & & & $\begin{array}{l}0.061 \\
(0.088)\end{array}$ & \\
\hline Treatment $\times$ skill intensity & & & & & $\begin{array}{l}0.084 \\
(0.155)\end{array}$ \\
\hline Fixed effects & $\begin{array}{l}\text { ctry-dt, } \\
\text { Pair-ind }\end{array}$ & $\begin{array}{l}\text { ctry-dt, } \\
\text { Pair-ind }\end{array}$ & $\begin{array}{l}\text { ctry-dt, } \\
\text { Pair-ind }\end{array}$ & $\begin{array}{l}\text { ctry-dt, } \\
\text { Pair-ind }\end{array}$ & $\begin{array}{l}\text { ctry-dt, } \\
\text { Pair-ind }\end{array}$ \\
\hline Sample & Top 50 & w/o Arab league & w/o Russia & All & All \\
\hline Observations & 237,463 & 371,827 & 359,753 & 410,303 & 410,303 \\
\hline $\mathrm{R}^{2}$ & 0.929 & 0.918 & 0.914 & 0.913 & 0.913 \\
\hline Adjusted $\mathrm{R}^{2}$ & 0.927 & 0.914 & 0.910 & 0.908 & 0.908 \\
\hline
\end{tabular}

$* p<0.1 ; * * p<0.05 ; * * * p<0.01$

\section{Robustness Tests}

We conduct a series of robustness tests to validate the findings against a number of potential concerns that are related to the sample or other confounding variables.

In Table 2 columns (1)-(3) we re-estimate Eq. (4) on three subsamples. One concern is that the coefficients from our benchmark estimation are driven by outliers: Small economies that for reasons other than bilateral diplomatic relations decrease their exports to the five countries of interest after being "treated" by one of the events described above. In column (1) we report the coefficients when selecting only the 50 largest economies out of the 241 countries that are present in the data as sourcing countries. The coefficients on the terms of interest retain the same sign and stay within a standard error of the baseline results in Table 1, despite the number of observations being cut by $42 \%$.

A further concern could be that the results are driven by the events that occurred in connection with the so-called Arab spring, which is in the time window of the data that we use. The summoning of the respective ambassadors was relatively 
common. ${ }^{14}$ The events coincided with security crises in these countries that could equally cause a sharp decline in imports, driving the reported results. We therefore re-ran the estimation of Eq. (4) on only non-Arab league countries. We find that the concern is not merited: The coefficients in column (2) remain very similar.

Another concern could be on the side of the importing country, as we were able to collect data only on diplomatic events from five major geopolitical players. One of the countries-Russia-could be of particular concern, as it could be argued that the country conducts its foreign policy structurally differently from Western countries and Japan. We therefore re-ran the estimation without events that involved the Russian Federation. Column (3) shows that this concern is also not merited.

A different concern involves the mechanism itself: The results could be driven by industry-specific factors that are not captured by the employed fixed effects. It could be that certain industries-which are labor or skill-intensive-react differently to a sudden change in bilateral diplomatic relations than do others. We test this assertion by estimating Eq. (4) with an additional interaction of indicators that are derived from the WIOD dataset on the labor and skill-intensity of sectors. Columns (4) and (5) in Table 2 show again that these concerns are not merited. Neither the interaction with labor-intensity, nor the interaction with skill-intensity are significant, and the coefficients of interest retain the same sign and stay within a standard error of the results of the benchmark specification that were reported in Table 1.

\section{Conclusion}

This paper contributes to the literature that studies the impact of diplomatic relations on trade in showing that the impact is heterogeneous across industries, owing to the entanglement of industries in global value chains.

Specifically, we show that imports of products that are used as inputs in a domestic economy intensively are more sensitive to negative diplomatic shocks than are other imports. We develop a simple theoretical framework that exhibits the mechanism and then test the mechanism empirically in reduced-form. We estimate the effect of sudden shocks to diplomatic relations on the import flows of five economically and politically important countries with the use of a novel dataset on diplomatic incidents: The summoning and recalling of an ambassador or other high-level diplomats. The econometric results provide evidence for the mechanism exhibited by the model. Diplomatic relations have a heterogeneous impact on imported inputs, driven by the importing country's direct and indirect use of imported input, controlling for the ease of switching sourcing partners.

The theoretical framework depicts a stylized version of the world economy with domestic and international input-output linkages. While the simplicity is attractive to highlight the mechanism at play, there are obvious simplifications that could be addressed in more involved models. In particular: One could imagine a richer characterization of the inner workings of the economy and explicitly model firms'

14 See "Appendix A.2" for the list of events. 
decisions in a political economy framework. As the main point is to establish the basic mechanism at play; however, this is beyond the scope of the current project.

Looking at the current state of the world of bilateral political relations and the status quo of research on the nexus of politics, trade, and global value chains, we see ample room for further research. As hinted at above, future work could investigate the role of firms, taking cues from the literature on the political economy of protectionism and recent work on the impact of tariffs in a world that is characterized by global value chains. Furthermore, we do wonder about the underlying mechanisms that may affect the exporting side, as is briefly mentioned in current research on sanctions. We refer these intriguing questions to future research.

Acknowledgements Open Access funding provided by Projekt DEAL. We thank Lionel Fontagné, Matthieu Crozet, Thomas Chaney, Jeffrey Nugent, Maria Bas, Keith Head, Vincent Vicard, Ariell Reshef, Holger Görg, and participants of the GSIE seminar, ETSG 2015, ERF Forum 2016, SMYE 2016 and the Doctorissimes for their comments and suggestions. The project leading to this paper has received funding from the European Union's Horizon 2020 research and innovation programme under Grant Agreement No. 770680.

Open Access This article is licensed under a Creative Commons Attribution 4.0 International License, which permits use, sharing, adaptation, distribution and reproduction in any medium or format, as long as you give appropriate credit to the original author(s) and the source, provide a link to the Creative Commons licence, and indicate if changes were made. The images or other third party material in this article are included in the article's Creative Commons licence, unless indicated otherwise in a credit line to the material. If material is not included in the article's Creative Commons licence and your intended use is not permitted by statutory regulation or exceeds the permitted use, you will need to obtain permission directly from the copyright holder. To view a copy of this licence, visit http://creativecommons.org/licen ses/by/4.0/.

\section{Appendix A: Press Releases from Ministries of Foreign Affairs}

\section{A.1 Links to Websites of Foreign Ministries}

- France: http://www.diplomatie.gouv.fr/en/

- Germany: http://www.auswaertiges-amt.de/

- Japan: http://www.mofa.go.jp

- Russian Federation: http://www.mid.ru/

- United Kingdom: http://www.gov.uk/government/organisations/foreign-commo nwealth-office

\section{A.2 List of Events}

See Table 3. 


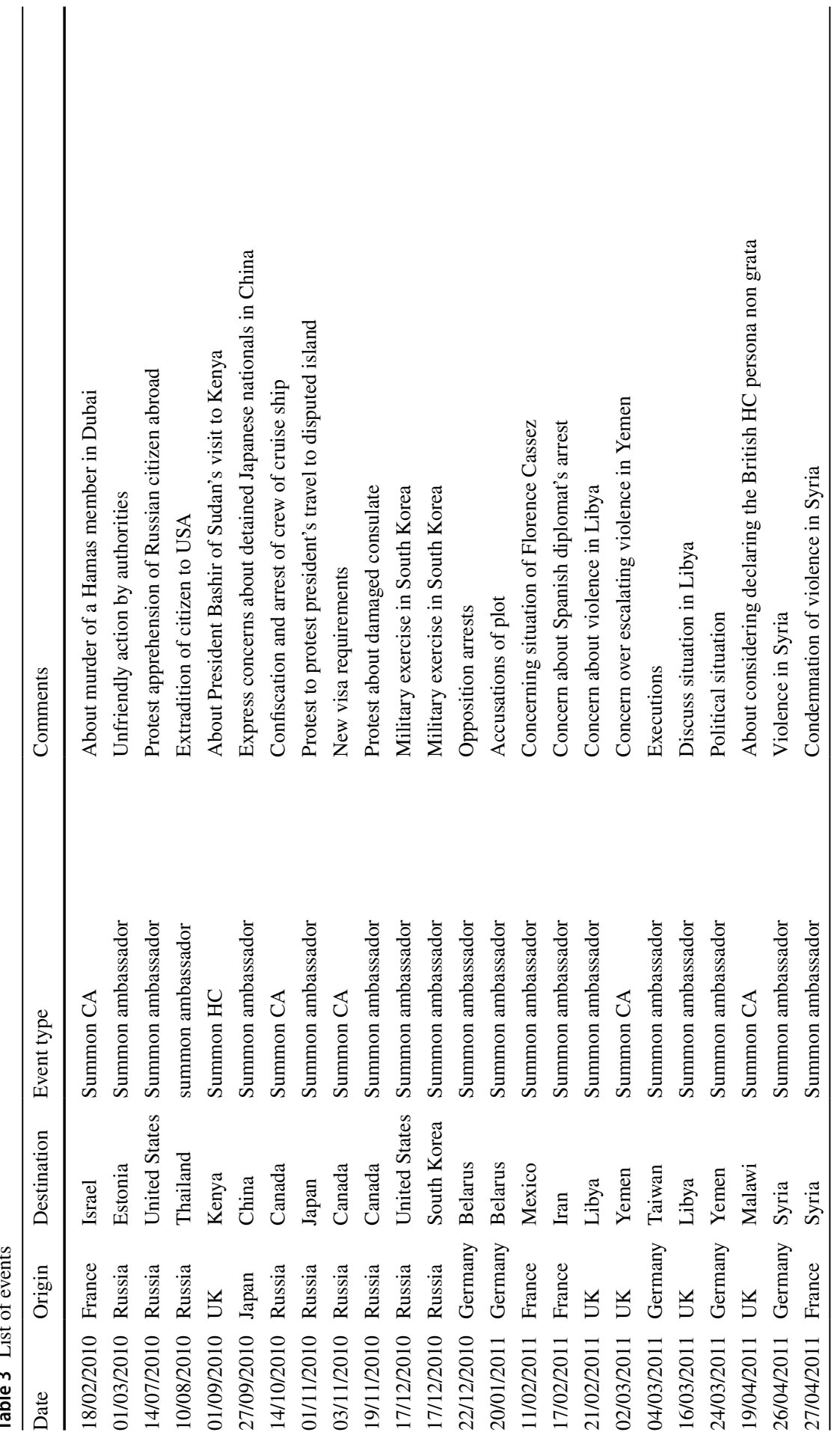




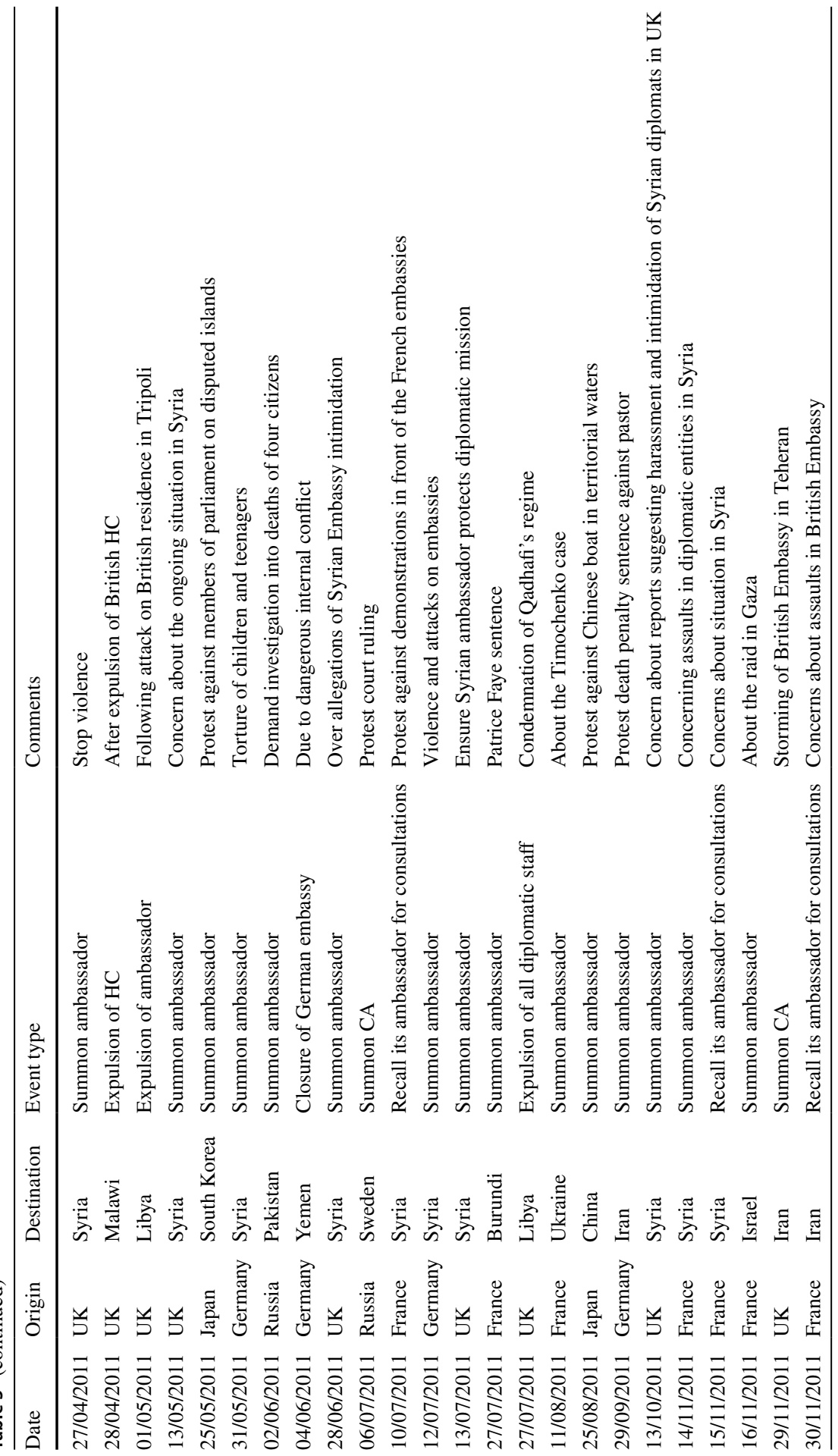




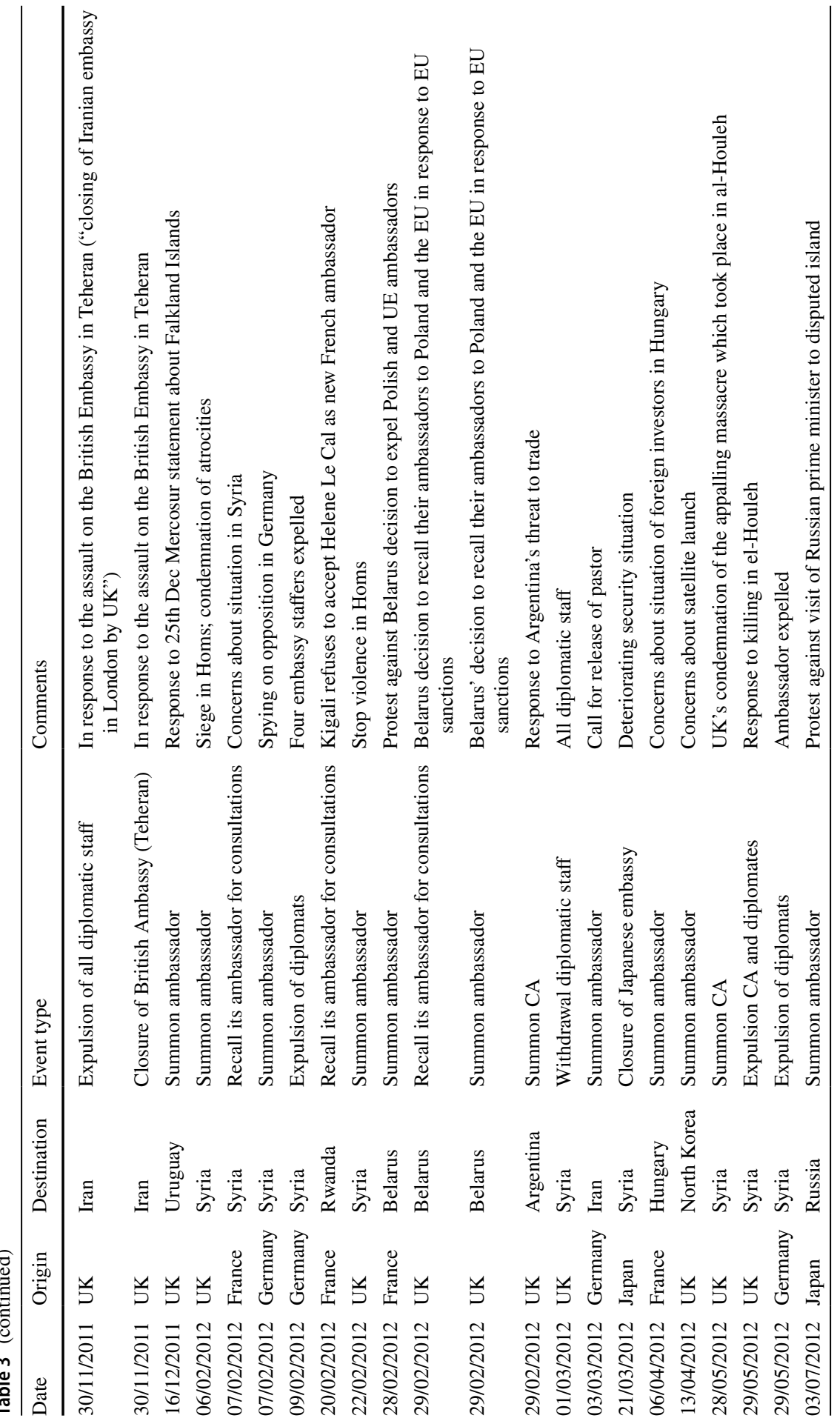




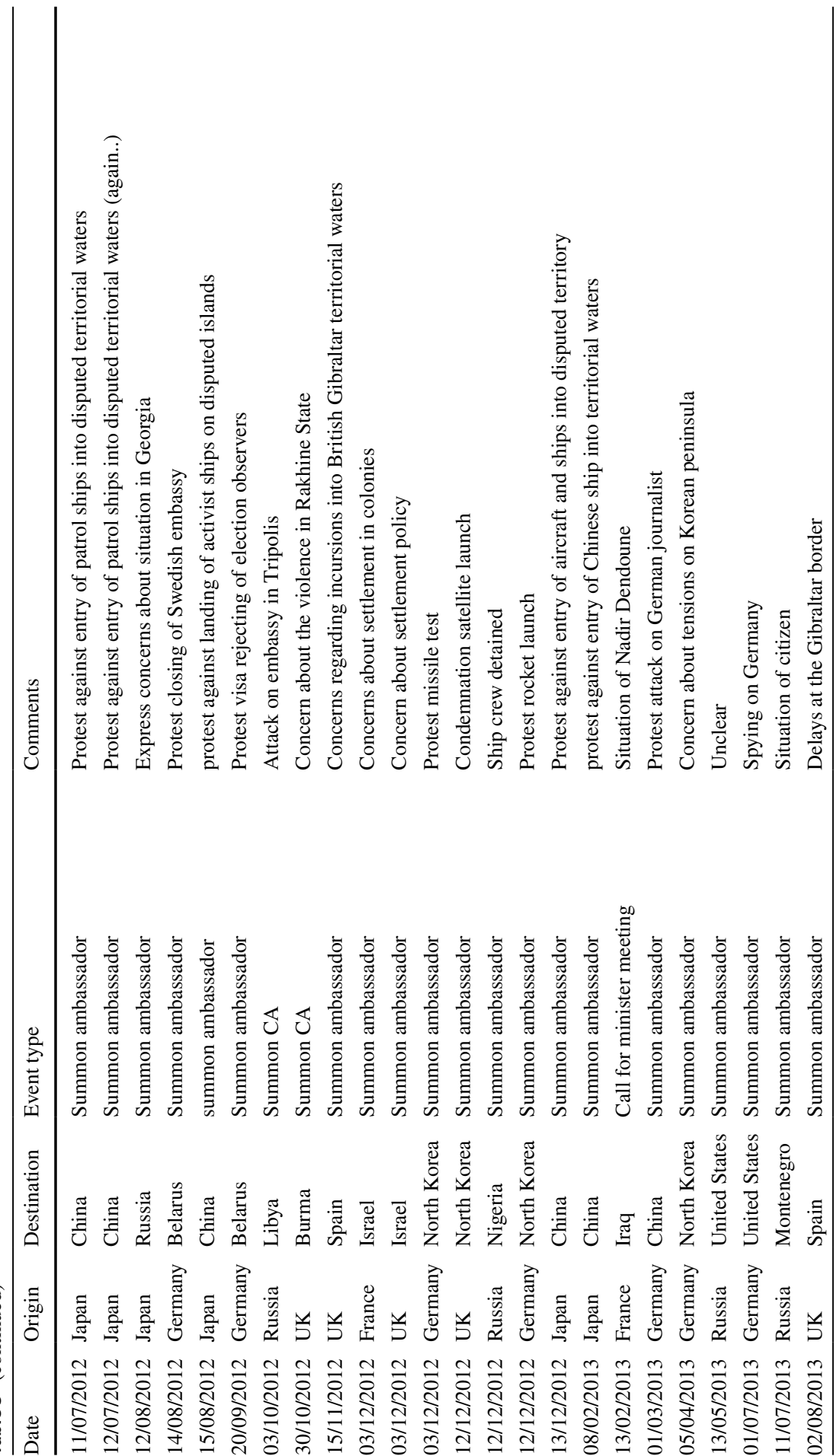




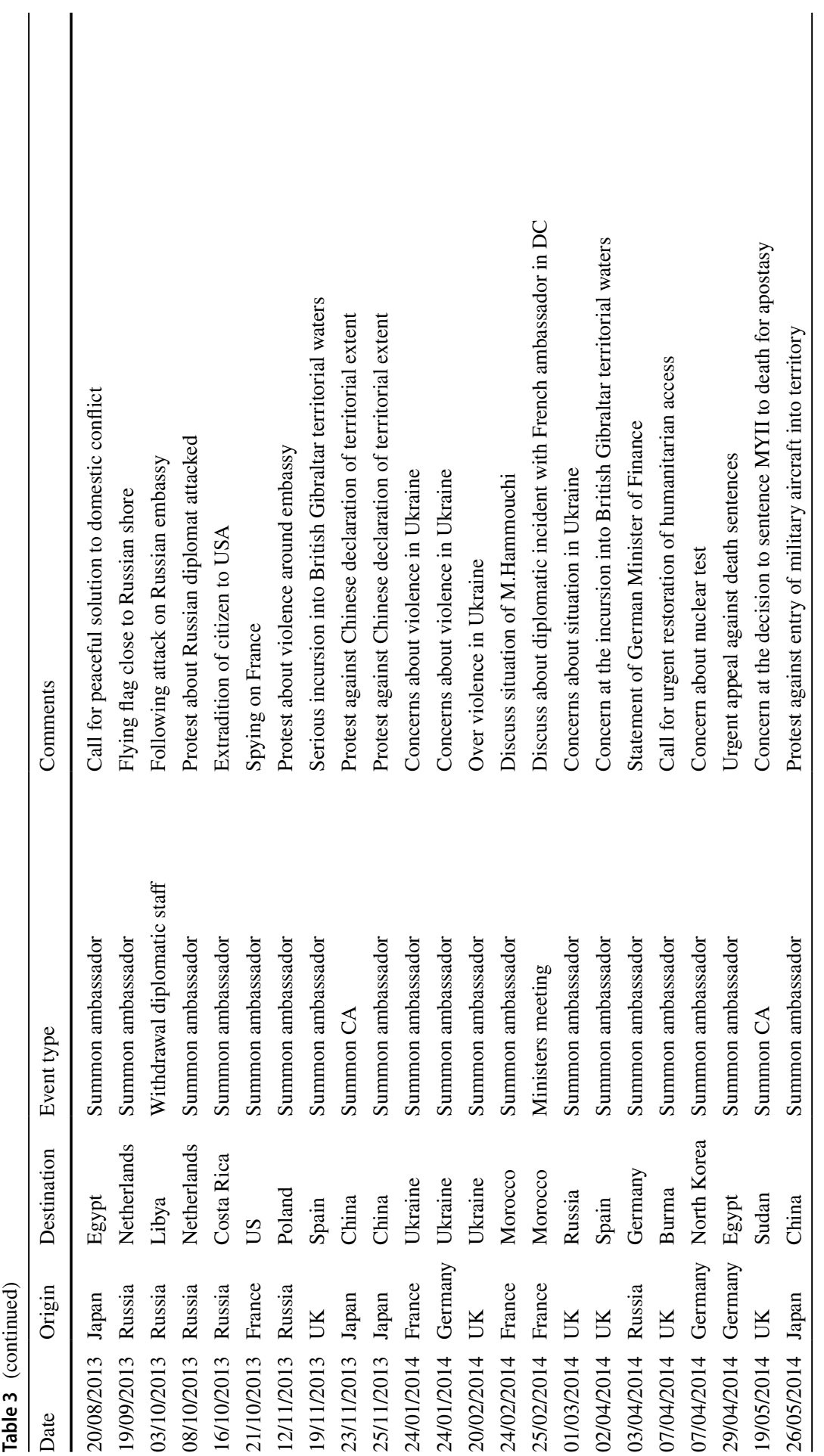




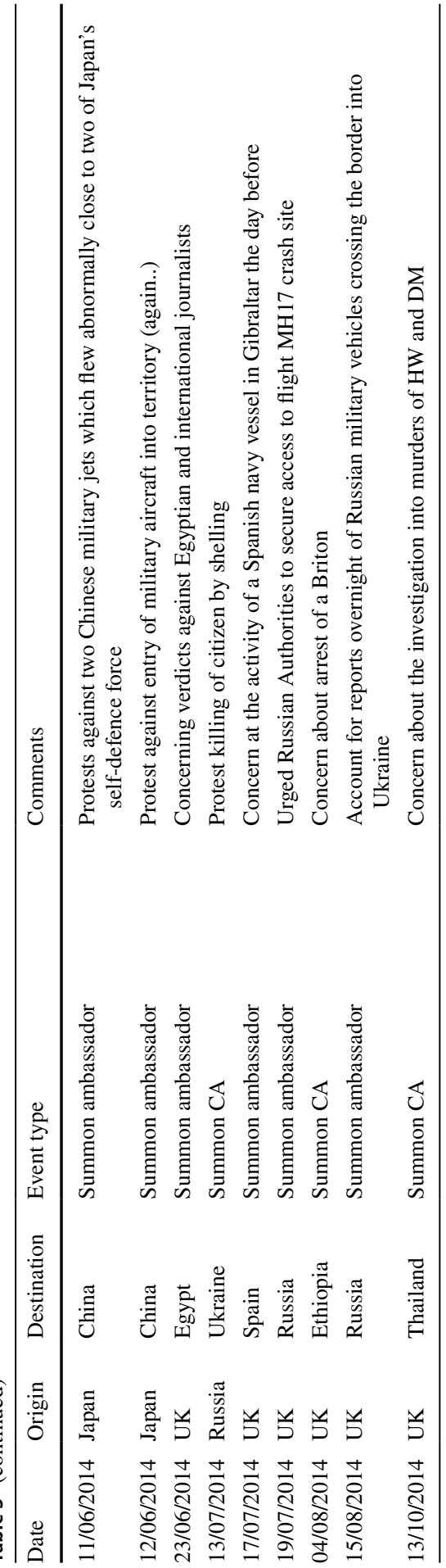




\section{Appendix B: Imported Input Use with Detailed Input Output Data}

\section{See Table 4.}

Table 4 Top 20 US industries by imported input use with BEA (top) and WIOD data (bottom) per \$1000 GDP)

\begin{tabular}{|c|c|c|}
\hline & BEA industry & Imported input use \\
\hline 1 & Oil and gas extraction & 13.12 \\
\hline 2 & Petroleum refineries & 4.14 \\
\hline 3 & Insurance carriers & 3.31 \\
\hline 4 & Iron and steel mills and ferroalloy manufacturing & 1.73 \\
\hline 5 & Other motor vehicle parts manufacturing & 1.62 \\
\hline 6 & Computer terminals and other computer peripheral equipment manufacturing & 1.36 \\
\hline 7 & Pharmaceutical preparation manufacturing & 1.26 \\
\hline 8 & Management consulting services & 1.21 \\
\hline 9 & Other basic organic chemical manufacturing & 1.19 \\
\hline 10 & Motor vehicle gasoline engine and engine parts manufacturing & 1.17 \\
\hline 11 & Semiconductor and related device manufacturing & 0.84 \\
\hline 12 & Other electronic component manufacturing & 0.81 \\
\hline 13 & Motor vehicle transmission and power train parts manufacturing & 0.81 \\
\hline 14 & Other plastics product manufacturing & 0.72 \\
\hline 15 & Fishing, hunting and trapping & 0.70 \\
\hline 16 & Telephone apparatus manufacturing & 0.69 \\
\hline 17 & Plastics material and resin manufacturing & 0.67 \\
\hline 18 & $\begin{array}{l}\text { Primary smelting and refining of nonferrous metal (except copper and alu- } \\
\text { minum) }\end{array}$ & 0.66 \\
\hline 19 & Other engine equipment manufacturing & 0.64 \\
\hline \multirow[t]{2}{*}{20} & Broadcast and wireless communications equipment & 0.63 \\
\hline & WIOD industry & Imported input use \\
\hline 1 & Coke, Refined Petroleum and Nuclear Fuel & 115.50 \\
\hline 2 & Public Admin and Defence; Compulsory Social Security & 55.49 \\
\hline 3 & Transport Equipment & 50.20 \\
\hline 4 & Renting of M\&Eq and Other Business Activities & 34.62 \\
\hline 5 & Financial Intermediation & 34.11 \\
\hline 6 & Chemicals and Chemical Products & 33.40 \\
\hline 7 & Construction & 28.59 \\
\hline 8 & Basic Metals and Fabricated Metal & 28.00 \\
\hline 9 & Food, Beverages and Tobacco & 25.33 \\
\hline 10 & Electrical and Optical Equipment & 22.66 \\
\hline 11 & Health and Social Work & 22.26 \\
\hline 12 & Mining and Quarrying & 19.20 \\
\hline 13 & Machinery, Nec & 17.69 \\
\hline 14 & Electricity, Gas and Water Supply & 16.03 \\
\hline
\end{tabular}


Table 4 (continued)

WIOD industry

Imported input use

15 Wholesale Trade and Commission Trade, Except of Motor Vehicles and

15.57 Motorcycles

16 Retail Trade, Except of Motor Vehicles and Motorcycles; Repair of Household 14.64 Goods

17 Pulp, Paper, Paper, Printing and Publishing 14.52

18 Other Community, Social and Personal Services 13.52

19 Hotels and Restaurants $\quad 13.27$

20 Real Estate Activities $\quad 11.81$

\section{References}

Amiti, M., Redding, S. J., \& Weinstein, D. E. (2019). The impact of the 2018 tariffs on prices and welfare. Journal of Economic Perspectives, 33(4), 187-210.

Born, B., Müller, G. J., Schularick, M., \& Sedláčk, P. (2019). The costs of economic nationalism: Evidence from the Brexit experiment. The Economic Journal, 129(623), 2722-2744.

Breinlich, H., Leromain, E., Novy, D., Sampson, T., \& Usman, A. (2018). The economic effects of Brexit: Evidence from the stock market. Fiscal Studies, 39(4), 581-623.

Crowley, M., Exton, O., \& Han L.(2018). Renegotiation of trade agreements and firm exporting decisions: Evidence from the impact of Brexit on UK exports. Technical report, University of Cambridge.

Crozet, M., \& Hinz, J. (2020). Friendly fire: The trade impact of the Russia sanctions and counter-sanctions. Economic Policy (forthcoming).

Cucu, F., \& Panon, L. (2020). Asylum policies, international tensions and trade flows: Evidence from the $E U$. Technical report, Sciences Po Paris.

Davies, R. B., \& Studnicka, Z. (2018). The heterogeneous impact of Brexit: Early indications from the FTSE. European Economic Review, 110, 1-17.

Fajgelbaum, P. D., Goldberg, P. K., Kennedy, P. J., \& Khandelwal, A. K. (2019). The return to protectionism. The Quarterly Journal of Economics, 135(1), 1-55.

Felbermayr, G., Jung, B., \& Larch, M. (2013). Optimal tariffs, retaliation, and the welfare loss from tariff wars in the Melitz model. Journal of International Economics, 89(1), 13-25.

Fuchs, A., \& Klann, N.-H. (2013). Paying a visit: The Dalai Lama effect on international trade. Journal of International Economics, 91(1), 164-177.

Heilmann, K. (2016). Does political conflict hurt trade? Evidence from consumer boycotts. Journal of International Economics, 99, 179-191.

Lin, F., Hu, C., \& Fuchs, A. (2019). How do firms respond to political tensions? The heterogeneity of the Dalai Lama effect on trade. China Economic Review, 54, 73-93.

Michaels, G., \& Zhi, X. (2010). Freedom fries. American Economic Journal: Applied Economics, 2(3), 256-81.

Mityakov, S., Tang, H., \& Tsui, K. K. (2013). International politics and import diversification. Journal of Law and Economics, 56(4), 1091-1121.

Nitsch, V. (2007). State visits and international trade. The World Economy, 30(12), 1797-1816.

Ossa, R. (2014). Trade wars and trade talks with data. American Economic Review, 104(12), 4104-46.

Romalis, J., Caliendo, L., Feenstra, R. C., \& Taylor A. M. (2019). A second-best argument to promote manufacturing with trade subsidies on intermediate inputs. Technical report, University of Sydney.

Rose, A. K. (2007). The foreign service and foreign trade: Embassies as export promotion. The World Economy, 30(1), 22-38.

Timmer, M. P., Dietzenbacher, E., Los, B., Stehrer, R., \& Vries, G. J. (2015). An illustrated user guide to the World input-output database: The case of global automotive production. Review of International Economics, 23(3), 575-605. 
United Nations Statistics Division. (2015). UN COMTRADE. http://comtrade.un.org/.

Publisher's Note Springer Nature remains neutral with regard to jurisdictional claims in published maps and institutional affiliations. 